\section{La Révolution française}

Cahiers de l'Institut d'histoire de la Révolution française

$11 \mid 2016$

L'Irlande et la France à l'époque de la République atlantique

\title{
Hibernian Sans-Culottes? Dublin's Artisans and Radical Politics 1790-1798
}

\section{Timothy Murtagh}

\section{(2) OpenEdition \\ Journals}

Electronic version

URL: http://journals.openedition.org//rf/1643

DOI: $10.4000 /$ Irf. 1643

ISSN: 2105-2557

\section{Publisher}

IHMC - Institut d'histoire moderne et contemporaine (UMR 8066)

\section{Printed version}

Date of publication: 1 December 2016

\section{Electronic reference}

Timothy Murtagh, « Hibernian Sans-Culottes? Dublin's Artisans and Radical Politics 1790-1798 », La Révolution française [Online], 11 | 2016, Online since 01 December 2016, connection on 19 April 2019. URL : http://journals.openedition.org//rf/1643 ; DOI : 10.4000/Irf.1643

This text was automatically generated on 19 April 2019

(C) La Révolution française 


\title{
Hibernian Sans-Culottes? Dublin's Artisans and Radical Politics 1790-1798
}

\author{
Timothy Murtagh
}

\section{Introduction}

1 A brief examination of revolutions and rebellions across history quickly reveals the importance of a country's capital city in ensuring the success or failure of an attempted uprising. A capital city is usually by definition the seat of government and therefore the only site from which a local insurrection can potentially seize control of the state. Paris is the obvious example, being key to revolutions in France during 1789, 1830 and 1848. However, other capital cities in Europe and South America played a similar role during revolutions in the nineteenth century ${ }^{1}$. Would-be revolutionaries during the $1790 \mathrm{~s}$ certainly appreciated the importance of seizing the metropolis, with the failed revolutionary coups of Robert Watt in Edinburgh, Col. Despard in London, and Babeuf in Paris, all attesting to the central role that a capital city would play in any seizure of power. Yet this simple observation does not seem to apply to Ireland, the one part of the British Isles that actually experienced a violent uprising in the form of the 1798 Rebellion. This was an outbreak of violence which cost the lives as many as 15,000 people, witnessed the landing of French troops on Irish soil, and has been labelled everything from a 'rebellion' or 'revolution' to a 'peasant uprising' or a 'civil war'2'. Importantly, this was also an overwhelming rural event - Dublin did not witness a rising during 1798. While parts of Leinster and east Ulster broke out into violent upheaval, the authorities kept a firm hold on Dublin. The Irish administration was well aware of the importance of Dublin to any potential uprising and had taken counter-measures. A series of arrests, coupled with the penetration by informers of United Irish networks in the city, meant that Dublin Castle was well informed of the plans of any potential rebels within the city. On the night of 23 May, the chosen date for the rising, the authorities flooded the planned rallying points and thoroughfares in Dublin with yeomanry and army detachments ${ }^{3}$. 
2 Yet if Dublin did not rise in insurrection in 1798, the authorities were under no illusion concerning the prevalence of 'disaffection' within the city. In the months before the rebellion, estimates of United Irish membership within the city ranged from between 5,000 to 10,000 . The extent of disaffection among the city's working population would have come as no surprise to the authorities. The city housed a well-known network of popular clubs. In the immediate wake of French Revolution, several Irish commentators had recognized the new popularity of political clubs among Dublin's menu peuple. As one pamphlet recounted, 'The mode of assembling in clubs or small societies, in which politics were discussed and debated, became general, and every porter-house could boast a set of statesmen, who [...] conceived themselves competent to every branch of legislative occupation $^{4}$. Richard Musgrave, one of the first chroniclers of the 1798 Rebellion, later claimed that 'labourers, tradesmen and even ragged apprentice boys, enlightened by attending reading societies, were taught [...] to think themselves amply qualified to dethrone kings, and regulate states ${ }^{5}$.

3 Curiously, the activity of these political clubs among Irish craftsmen has attracted little attention. Most histories instead focus on the United Irishmen, an initially middle-class group which only transformed themselves into a 'mass-based secret society' following their formal suppression in $1794^{6}$. This is surprising considering the rich comparative literature concerning the activities of American, French and British artisans in precisely this period ${ }^{7}$. This article investigates whether Dublin's artisans were in any way an Irish equivalent to the Parisian 'sans culottes'. In the context of the present discussion, the term 'sans culottes' is used quite loosely, to refer to groups of politically literate artisans who harbored their own idiosyncratic form of republicanism. This somewhat vague definition is due to the limitations inherent to a more rigorous comparison with the Parisian sans-culottes. 'Sans-culottes' was a term which could blur the line between socioeconomic identities and political commitments, in a way that has proven contentious for historians of the movement ever since. Modern historians have hotly debated both the socio-economic coordinates of the 'sans culottes', as well as the linguistic nuances of the term as the product of a particular political and intellectual culture ${ }^{8}$. Conversely, in the mouths of British conservatives during the 1790s, the label was often used as a catch-all description for any aspect of the urban working population deemed dangerous or potentially seditious. Within several years of the Revolution, a proliferation of literature would delight in depicting the poisonous effects of revolution on domestic artisans. After 1789, Dublin's artisans would, much like artisans throughout the British Isles, were frequently included within these broad descriptions as 'blood thirsty democrats' and 'sans culottes'.

4 While this article seeks to use the term with slightly more precision than simply a synonym for 'the rabble' or 'the mob', it is not suggesting that Dublin's skilled workers inhabited the same intellectual or social universe as the Parisian sans-culottes. Instead it merely suggests that, in an Irish context, Dublin's artisans represented a unique constituency: a non-elite yet politically literate group who imbibed the new revolutionary doctrines emanating from France. While the focus of Irish historians has been firmly on the emergence of the United Irishmen in 1791, this article instead focuses on the series of independent lower-class political societies in the Irish capital who were engaging with many of the same ideas and intellectual currents as their middle-class counterparts. While the social structures and urban cultures of Paris and Dublin may have been dramatically different, each nonetheless contained a population of politicized artisans, 
whose ethos and ideology built upon workshop traditions and practices, as well as a plebeian 'tavern' culture of conviviality and debate ${ }^{10}$. This article outlines how, much as in Paris, Dublin's artisan radicals were the product of several decades of industrial agitation, as well as being the culmination of successive political campaigns in which tradesmen were invoked by local politicians. It will further show how Dublin's artisans came to create their own autonomous network of political societies, as well as illustrating how middle-class radicals came to recognize the potential of these artisan debate clubs, eventually developing links between plebeian groups and a wider revolutionary organization. Despite the numerous differences, Dublin resembled Paris at least in one aspect: a tentative alliance between middle-class 'Jacobins' (however defined) and the mass of urban craftsmen and mechanics in the city in which they lived. This article will explore how this alliance both shaped and restricted the potential of Dublin's popular politics.

\section{Dublin: Social and Economic Background}

While comparisons of Dublin with a metropolitan city like Paris may seem trite, Dublin was far from being a backwater. In the eighteenth century, it was second city of the British Empire. Its range of services and functions made it unique in Ireland; in addition to being the social and cultural epicentre of the Anglo-Irish 'ascendancy', it was the administrative, legal and financial hub of the island. By the 1760s Dublin was the hub of an integrated transport and communications network of canals, roads and postal services, while the city's economic ascendancy was partly the result of a process of national market integration ${ }^{11}$. Combined with the dominance of Dublin's print trade on the island, the city stood uniquely poised to act as the transmitter of new fashions and ideas to the countryside ${ }^{12}$. By mid-century, Dublin had a population of approximately 125,000 people, making it the ninth largest city in Europe. By the end of the century, the city's population had grown to 180,000 . Significantly though, of the top ten most populous cities in Europe, Dublin was the only one on the list that was not the capital of a sovereign state ${ }^{13}$. This quirk in some ways reflected the anomalous nature of Ireland within the British Empire. Dublin exhibited some of the characteristics of a capital city, such as housing a parliament, but it was a parliament that had a complicated and subordinate relationship to Westminster. Dublin was the mercantile and manufacturing centre of the island, but Irish trade as a whole was subject to British restrictions which increasingly raised questions about the country's constitutional and economic standing within the Empire. Dublin was neither a metropolitan capital nor a colonial outpost.

6 In terms of the city's economic life, Dublin's rapid expansion in the earlier decades of the century had been driven not only by its role as a playground for the Irish elite, but also as a busy port and extensive manufacturing centre. Dublin was home to numerous luxury trades that catered to its elite residents, gold and silver smiths, coach-making and higherend tailoring and shoemaking. It also contained considerable enterprises in brewing, distilling and sugar refining, as well as a booming construction sector as a result of the city's physical growth. At the end of the eighteenth century Dublin was still a city of workshops; although, by the 1770s, the city was facing increasing economic challenges due to competition with imported goods and its own limited economies of scale. Nonetheless, the city's manufacturing districts were still some of the densest on the island, with textile manufacturing providing work for 15,000 to 20,000 men and women in 
Dublin, most packed into the dense manufacturing neighbourhoods in the south-west of the city ${ }^{14}$.

7 While the city's working life was supposedly regulated by Dublin Corporation and the guilds, the pretensions of the guilds to act as regulators of trade had been undermined by Dublin's changing denominational balance. The exclusive Protestant nature of the guilds and of the Corporation meant that Catholic tradesmen and retailers were officially outside of its bounds. Following the example of London, Dublin had introduced a 'quarterage' system whereby Catholics paying a quarterly fee were entitled to the status of 'quarter brother' and allowed to practice their trade, although without the full political privileges or influence of being a full member of a guild. 'Quarterage' allowed the guilds to retain control over tradesmen of all denominations while maintaining the guilds as Protestant monopolies. This religious dimension may well be a factor in explaining why the Dublin guilds retained some stake in the economic system longer than in many other western European countries. However, the rapid growth of the city's Catholic population (Catholics probably constituted 70\% of the city's population by the last decade of the century) meant that there was increasing resistance to guild regulation by Catholic tradesmen ${ }^{15}$. For their part, Protestant employers were also increasingly unwilling to abide by all the various restrictions that guild regulation entailed, particularly in relation to limits on the number of apprentices they could keep. The ability to hire larger numbers of employees (with looser and more flexible contracts) was of particular concern to the few manufacturers who were attempting to expand their scales of production. While the size of units of production in Dublin during the last years of the eighteenth century remained small, some larger works did exist - some firms within the city employed several hundred men, particularly those specializing in textile printing ${ }^{16}$. However, the overall trend was towards building these larger manufactories outside the city itself.

8 The challenges that new, proto-industrial forms of manufacturing posed to 'traditional' employment patterns also produced a response from Dublin's wage-earners. Underneath the official corporate structure of the guilds, the city's journeymen had organized themselves into independent clubs known as 'combinations' (essentially pre-industrial trade unions), which sought higher wages, shorter hours and restricted access to their craft. While these 'combinations' have sometimes been compared to French compagnonnage, these groups did not share the same quasi-masonic ethos of elaborate histories and rituals, nor did they have geographically large networks as in France. These 'combinations' were closer to the groups of journeymen that emerged in Paris during the 1770 s and 1780 s, in that they were more pragmatic responses to immediate conflict with the masters ${ }^{17}$.

9 By the end of the eighteenth century, these journeyman 'combinations' existed in almost every branch of trade in Dublin. In the year 1792 along, a list of the trades involved in labour disputes comprised 14 separate trades, including linen weavers, smiths, wool combers, flax dressers, rope-makers, ship carpenters, paper manufacturers, brick layers, cutlers, shoemakers and glovers ${ }^{18}$. Some of these labour organizations demonstrated impressive resources, with certain groups capable of withstanding strikes of several months. Not only were workers well-organized within their individual trades, but there was extensive cooperation between the different trades. This was demonstrated in both 1780 and 1792, when new anti-trade union legislation was suggested in the Irish House of Commons. In both 1780 and 1792, workers from all of the city's various trades staged 
mass processions to the parliament in College Green in demonstration against the proposed legislation. In 1792, one such march allegedly numbered as many as 10,000 men, making it one of the largest demonstrations of the era ${ }^{19}$. In both incidences the city's artisans contributed to a common stock purse, paying for legal representation, holding correspondence between all the various trades and agitated in unison to demonstrate against the new legislation.

In 1803, one government informer described how a system of voting for trade delegates had functioned within the city's workshops for the previous several decades: 'one man is deputed by the men from each shop. From these deputies there is a president, a secretary and two stewards chosen and then the election ceases and a report is made to the shops of the appointments'. While each workshop subscribed money to the trades' committee, there was a constant report back from their representatives, whom they were free to recall ${ }^{20}$. It was through these traditions that men learned democracy in a very immediate and real way. The election of delegates, the management of collective funds, the process of chairing a meeting or corresponding with other groups-these are skills that are crucial to political organisation and which these journeymen had to learn out of necessity. More to the point, these were traditions in which elected representatives could be held immediately to account and where democratic practice was continual. In some respects, the very experience of being an artisan lent itself to the reception of new democratic and egalitarian ideas. Being a journeyman, a qualified worker, meant an end to the subservience of being an apprentice and having the freedom to choose and change employers. But although they spoke of themselves as free, they knew they lacked the independence that came with running one's own business and were thus sensitive to any infringement on their 'independence'.

\section{The Emergence of Popular Politics 1720-1780}

11 In addition to the experience that came from trade organization or workshop experience, Dublin's artisans had been habitually called out into popular demonstrations by several generations of Irish politicians. Over the course of the eighteenth century, a series of controversies had resulted in popular demonstrations in Dublin, largely engineered by Irish politicians who found them in opposition to the governing executive imposed from London. During the 1720s, a dispute over Ireland's coinage, known as the Wood's HalfPence dispute, had prompted a loud and sustained outcry, with a series of pamphlets by Jonathan Swift in his persona as the 'Drapier' being the best known. The dispute had also provoked several disturbances among Dublin's artisans, with effigies of the offending William Wood being burned in the city, indicating the resonance the issue had with urban workers ${ }^{21}$.

An even bigger controversy erupted in the city in the year 1749, when a popular guild representative named Charles Lucas ran for a seat in the Irish House of Commons. The resulting campaign included several innovative aspects, such as the widespread use of printed materials, particularly newspapers, and numerous political meetings, many taking place within guildhall meetings ${ }^{22}$. Lucas was notably for his defense of the right of tradesmen to participate in political debate, arguing that any artisan, as long as they displayed 'integrity and capacity' to 'fulfill his duties', deserved a vote, 'though he had the very morning of his election, come out of his forge, his shop or his workhouse ${ }^{23}$. This broader vision of the electorate was reflected in other areas of Lucas's thought, 
particularly his belief that members of parliament were only servants to their constituents. During the 1749 campaign, Lucas indicated that, if elected, he would be guided by instructions from his constituents. This was a partly a continuation of the practice of guilds to use issue formal instructions to their representatives on the common council of Dublin Corporation ${ }^{24}$. It was this preference for popular over parliamentary sovereignty that would become a touchstone of the city's artisans later in the century.

In the immediate context of the 1750s, Lucas's particular brand of popular politics contributed to the rise of extra-parliamentary support for the Patriot faction in the 1750s, in which Lucas's rhetoric transcended being a municipal phenomenon into a national and parliamentary one. During the Money Bill dispute of 1753-6, the arguments Lucas had used were now deployed (sometimes quite cynically) by parliamentarians who styled themselves as 'Patriots'. While the dispute was ostensibly about a constitutional issue over the disposal of surplus revenues, it was essentially a factional struggle between elite groups. What transformed it into a crisis was the decision of one of the participants, Henry Boyle, and his allies to appeal to public opinion. Much like the 1749 election, a huge volume of printed material emerged out of the dispute - possibly over 175 pamphlets for 1753-1755 alone, including a lively body of satirical literature ${ }^{25}$. It also drew out crowds, such as in 1753 upon the occasion of a Patriot victory in defeating an altered money bill, when Boyle and the Earl of Kildare were escorted home in triumph by a crowd of a thousand people, with illuminations and bonfires in the city ${ }^{26}$.

However cynical the use of 'patriotic' arguments by Irish politicians may have been, the cumulative effect over several decades was that Irish workers came to closely identify their own economic well-being with the course of parliamentary politics. Furthermore, by the 1780s, several generations of Irish artisans had imbibed the rhetoric of Irish 'Patriots' who argued that Irish economic ills were the result of the island's constitutional subjugation to Britain. This was spectacularly demonstrated during the era of the American War of Independence, when the issue of British commercial restrictions on Ireland became the central issue of the day. Not only did crowds of workers come out to support popular causes such as commercial concessions in 1779 and constitutional reform in 1782, Dublin's artisans increasingly mobilised over issues such as protective tariffs, in the hope of defending their livelihoods from the threat of British imports. The influence of 'American' ideals also made their presence felt on Dublin's streets, with journeymen adopting the practice of 'tar and feathering' the importers of foreign goods. During the summer of 1784, there were thirteen separate instances of such attacks on foreign importers, with local authorities fearing a total breakdown of law and order. The violent demonstrations were so worrying to officials in Dublin Castle, that several government figures speculated upon a possible insurrectionary conspiracy within Dublin's working neighbourhoods, supposedly instigated by French or American agents ${ }^{27}$.

15 Crucial to many of the above events was the role of members of the Irish House of Commons, based in Dublin and willing to invoke popular support for their various causes. The presence of the Irish Parliament meant the city's working classes were in close quarters to the symbolic centres of power, a feature which existed in no other British city apart from London. The relative absence of popular politics in Edinburgh, following the abolition of the Scottish parliament in 1707, is instructive in this regard. While Edinburgh witnessed the infamous Porteous Riots of 1736, and experienced a short-lived period of popular anti-Walpole agitation in the 1740s, it failed to produce a vocal, civic politician in the mould of Dublin's Charles Lucas or London's William Beckford ${ }^{28}$. Due to the location of 
the Irish Parliament, Dublin's inhabitants had a more immediate and direct relation to formal politics than any other city in Ireland, and possibly any other city in Britain (apart from London).

16 Another factor in politicization is popular literacy. While Ireland could not rival either Britain or France, either in terms of overall literacy or newspaper circulation, it too contained a significant reading public. The statistics for Irish literacy in the eighteenth century are unreliable. However, a reasonable estimate of literacy in the late-eighteenth century is $55 \%$ among men and $34 \%$ among women ${ }^{29}$. Also, Dublin's literacy rates were undoubtedly higher than these national averages. Literacy and urbanisation go hand in hand - the city's artisans were immersed in constant market transactions which promoted basic reading skills. With the advantage of being outside the restrictions of British copyright legislation, Dublin was the second largest centre of printing in the English speaking world until the nineteenth century. By 1761, the city already had 45 printers and booksellers, rising to a height of 115 in 1796. As a result, Dublin had a vibrant culture of newspapers, with as many as 12 different papers being published in the city during the $1770 \mathrm{~s}^{30}$. Additional evidence of literacy can be found in the recourse of artisans to consulting the statutes of their corporation or the rulings of local authorities. As early as the 1750s, disturbances in the Irish capital were blamed on master tradesmen who read newspapers and who 'over a glass inflame their apprentices and journeymen ${ }^{31}$. By the 1780s, Dublin's journeymen frequently articulated their grievances and aspirations in letters to newspapers and even petitions to parliament. By the 1780s, Irish elites no longer had a monopoly on the written word.

\section{Dublin's Artisanal Radicals 1791-5}

It was both this high level of literacy, as well as a tradition of political engagement, that meant Dublin's workers were inclined to form radical debate clubs in the 1790s. During the early part of the decade, Dublin newspapers were full of references to numerous obscure political clubs springing up in the city such as the Union, the States, the Illuminati, the Spread, the Huguenots, the Clady, the Shoe, the Dexter, the Jason, the Shamrock, the Athenian, the Philanthropic and the Telegraphic societies ${ }^{32}$. The line between labour organization and revolutionary politics was increasingly blurred during the 1790s, with conservative newspapers relishing the application of revolutionary terminology to Dublin's journeymen groups. In 1794, the Freeman's Journal reported on a 'turn out convention of sans culotte journeymen shoemakers' assembling in Rathmines, jokingly referring to how they dealt with a man who would not join the combination, they 'might have doomed their prisoner to the guillotine, or at least a sousing in one of the levels of the Grand Canal ${ }^{33}$. The city's shoemakers seem to have had a reputation for radical politics, as later the same year, the Freeman's Journal once again reported on how 'a section of combining journeymen shoemakers who were surprised in high debate [...]. The master shoemakers that apprehended them having information of another department being convened in Winetavern street, they repaired there in order to apprehend the Revolutionists. But those we supposed were a Revolutionary Tribunal, for they sat armed in debate; and when the master shoemakers came upon them, made a sortie, in which they desperately wounded some of the employers. Three of them however were secured at the time, and a Marat of party was taken the following morning ${ }^{34}$ '. In another instance, it was reported that a 'council of five hundred journeymen tailors' had assembled in a field near 
the city to listen to the 'reports of their Committee of Public Welfare' passing resolutions against certain employers who had incurred their wrath by accepting British military contracts $^{35}$. In 1795, one Irish newspaper even went as far as to juxtapose the terminology of the French Terror with the names of Dublin's working-class districts: "the Terrorists of Pill lane, the Marats of Skinners-row, the republican chouans that nightly revel in Hoey's court and the Roberspierrean Pike committee of Suffolk Street" ${ }^{\text {"36 }}$.

This was undoubtedly the hostile rhetoric of newspaper editors: terms such as 'sans culottes' or 'Jacobin' were used by British conservatives almost as synonyms for terms like 'leveller' or 'anarchist ${ }^{37}$. They do not constitute evidence of any substantial similarity with the Parisian sans-culottes. Nonetheless, considering the proliferation of popular radical clubs in Dublin, these hysterical newspaper articles are at least suggestive of a broad political engagement by artisans. It can be argued that Dublin's artisans might be classified as an Irish 'sans culotterie' in that they were not only politically literate, but also sustained a political discourse in their clubs which was significantly different from that of Ireland's middle-class radicals. This is, admittedly, difficult to prove definitively. While much has been written about the origins and nature of middle-class Irish radicalism, we know comparatively little about the views and ideas of the more plebeian radicals in this period. We cannot recreate the mental world of a Dublin artisan to the same extent we can with more affluent radicals like Theobald Wolfe Tone or William Drennan, who left behind engaging diaries or letters. Nor do we have any first-hand account by an Irish journeyman that is comparable to some of the French examples, like the accounts by Jacques-Louis Ménétra, Louis-Sébastien Mercier, or Nicolas Contat. Unfortunately, there is no Irish equivalent to the 'Great Cat Massacre' on the Rue SaintSéverin which might allow for a social-anthropological investigation into the artisanal worldview ${ }^{38}$. Even so, using what fragmentary evidence available, we can make some shrewd guesses concerning what was being read and how these artisans may have interpreted material in light of their own experiences during the 1790 s.

Considering Thomas Paine's extraordinary reception in Ireland, the huge print and newspaper exposure of Rights of Man, it is reasonable to assume that Dublin artisans, like their London or Manchester counter-parts, were heavily influenced by Paine. A cheap edition of the first part of Rights of Man was distributed in Dublin during July 1791, while Part II received an even wider dissemination due to the efforts of several radical booksellers. The United Irishmen also helped produce subsidized editions, with reports of cheap (as little as 2 pennies) and in some cases free copies being distributed in Dublin and $\mathrm{Cork}^{39}$. One conservative Irish pamphleteer claimed that Paine had a lock on 'the mind of the Irish peasant and lower tradesman ${ }^{40}$. Yet Paine's writings were not especially aimed at working men or wage earners. His work equally appealed to farmers, shopkeepers, small masters and professionals. His views did not challenge property rights or the emerging doctrines of laissez faire. Like Adam Smith, Paine envisioned an egalitarian society of small producers, driven by self-improvement, unhindered by 'feudal' regulation or customs, where competition would prevent the accumulation of excessive wealth. While the fifth chapter of the Rights of Man part II contained proposals for state welfare and insurance against old age, and Agrarian Justice forwarded proposals concerning income redistribution, these were aimed at landed aristocracy, where the hereditary principle of primogeniture provided the rationale for Paine's attack ${ }^{41}$.

Paine had no truck with journeymen combinations and he offered no framework for asserting collective rights among the exploited or dispossessed. Paine was certainly 
popular among middle-class radicals such as the United Irishmen, several of whom were responsible for printing editions of Paine's works. Among these middle-class radicals Paine's writings probably 'confirmed rather than inspired' their agenda, but amongst the new political constituency of literate tradesmen, his work had a far more innovative effect. Paine's main target was not the wealthy so much as undeserved aristocratic opulence: Paine divided society into the 'productive' versus 'unproductive' classes, roughly defined as 'those who pay taxes, and those who receive and live upon taxes ${ }^{42}$ '. His emphasis was on the unnatural interference of privilege or oligarchy on the economy. However, if this analysis of productive and unproductive groups could be used by the middle class against aristocracy, it could also be appropriated by wage earners, who saw themselves as the actual producers of wealth.

In this regard, an examination of one of the other most popular radial writers of the era is instructive, the work of the Frenchman Constantine Francois de Volney, specifically his 1791 book The Ruins; or meditation on the Revolutions of Empires. Written in an engaging and accessible style, it was decried as one of most prolific 'corrupting' books of the various 'infidel' societies in London during the 1790s, while a Welsh translation was apparently in circulation by the middle of the decade ${ }^{43}$. A copy was found in Bahia, Brazil during 1797 and was linked to an insurrectionary conspiracy of mulattos and slaves, while a recent survey of the 'revolutionary Atlantic' has suggested that Volney's book may have been as important to the Age of Revolution as Paine's Rights of $\mathrm{Man}^{44}$. Significantly, Volney also had an extensive Irish reception. His works were included in a pamphlet that was 'industriously distributed to the peasantry of the north' between 1795 and $1797^{45}$. Richard Musgrave listed Volney, along with Paine and Godwin, as one of those authors 'which give wings to treason, and convey it to the garret and the cellar ${ }^{46}$. Government informers repeatedly passed on handbills based on Volney's writings back to the authorities. The 'Rebellion Papers' collection contains at least two separate editions (and numerous copies) of handbills taken from Volney's Ruins, particularly its fifteenth chapter a vision of a 'New Age' which takes the form of a dialogue between the 'people' and the 'privileged classes $^{47}$.

In this exchange, the 'People' quiz the 'Privileged Class' as to why they enjoy their riches while not laboring:

People: And what labour do you perform in our society?

Privileged Class: None, we are not made to work.

People: How, then, have you acquired these riches?

Privileged Class: By taking the pains to govern you.

People: What! Is this what you call governing? We toil and you enjoy! We produce

and you dissipate! Wealth proceeds from us, and you absorb it.

While Paine may have introduced the notion of 'productive' vs. 'unproductive' classes, setting the aristocracy against everyone else in society, in Volney there was the seed for a more radical partition of society: 'All the vices, all the political disorders, are deducible from this source; men who do nothing, and who devour the substance of others'.

Admittedly, the details of exactly how Dublin's artisans articulated their own interpretations of radical politics are largely speculative. Politicisation, as a process, is hard to delineate. In examining the process, the productions of the bourgeois revolutionaries designed to 'instruct' the popular classes are certainly an important factor. But, to reiterate, the 'indigenous' culture of artisans themselves was just as important. Radical and republican ideas may have been carried to urban artisans by the 
middle class, but they struck root among journeymen due to the independent culture which allowed such ideas to flourish. The rapid popularisation of Paine and Volney in the English-speaking world was due to a 'shock of recognition', as radical propaganda systematised pre-existing artisan attitudes.

\section{Artisans and the United Irishmen}

If works by Paine and Volney found a warm reception among Irish artisans, what of publications by Irish radicals? If the analogy of Dublin artisans with the Parisian sansculottes is questionable, what about their relationship to 'bourgois' radicals like the United Irishmen? Did the United Irishmen constitute an Irish equivalent to the 'Jacobins'? Much like the term 'sans culottes', the term 'Jacobin' or 'Jacobinism' is a complex and contested description, the discussion of which lies outside the remit of this article ${ }^{48}$. Broadly speaking, the United Irishmen resembled the Jacobins in some respects (an extensive system of affiliated clubs, a passionate commitment to political equality) while differing substantially in others (the Jacobins' fervent anticlericalism found only limited resonance within Irish radicalism). For the purposes of the current argument, we might restrict ourselves to two pertinent aspects of defining the United Irishmen as 'Jacobins': the social composition of their membership and their relationship to the urban crowd. In terms of composition, the members of the Dublin United Irishmen resembled the Marxist interpretation of the Jacobins as stereotypicaly 'bourgois'. Out of the initial membership of the Dublin Society (which lasted from 1791-4), a little over a quarter of its membership were professionals, particularly those practicising law, with the rest of the membership consisting mainly of wealthy manufacturers and merchants. It is unlikely that any of the members could be termed wage-earners or 'mechanics', with even those classified as 'tradesmen' being prosperous master craftsmen who owned their own shop or establishment. The substantial commercial and manufacturing presence within the society was nonetheless offset by an 'inner council' of (predominantly Protestant) professionals, who tended to dominate proceedings. The leading figures within the club were frequently those with a legal background (Tone, Emmet, the Sheares) ${ }^{49}$. In this very general sense there is an analogy to be made between United Irishmen and the Jacobins, in that both were composed of what might broadly be considered the 'middling sorts'.

The other aspect we might examine is the relationship of the group to the urban crowd. Did the United Irishmen seek to build and utilise an allance with Dublin's working artisans? It is useful to examine the attempts by the United Irishmen to appeal to urban workers via print. A generation of historians have been fascinated by the propaganda machine created by the United Irishmen in their attempt to 'make every man a poltician' - a torrent of poems, ballads, handbills, songbooks, and pamphlets ${ }^{50}$. Significantly, these United Irish productions made use of the very real economic grievances of Irish workers. A series of poor harvests had led to food riots in Dublin during 1795 and 1796, while the rapid growth of the Irish military budget after 1793 had also meant higher excise taxes. Urban wage earners felt the increased burden of indirect taxes in the 1790s, with alcohol, sugar, tea, salt, leather and tobacco all experiencing tax increases ${ }^{51}$. These disproportionately hit city dwellers. One attempt at producing a chart of real wages (adjusted for cost of living) has found a decline in real wages for unskilled labour in Dublin in the later 1790s. Taken in conjunction with evidence that urban rents were rising in the 1790s, the effect of the wars on urban workers was negative ${ }^{52}$. Add to this the 
very visible presence of recruiting parties and press gangs in the city, and it was not difficult for agitators to argue that the war was placing a substantial human, as well as financial, burden on the average Dubliner.

The United Irishmen were indeed certainly perceptive in targeting the material concerns of the capital's workers, as several widely distributed works confirm. Pamphlets like the Poor man's Catechism astutely argued that the hardships of artisans and labourers could be solved by 'the emancipation of [the] country, an equality of rights, a fair division of land, an abolition of religious establishments, and a representative government'. Several other United Irish productions similarly emphasized the benefits of abolishing tithes and redistributing church lands ${ }^{53}$. However, the question is whether any of this indicated real commitment to social reform by the United Irishmen. Several historians, notably Marianne Elliott and Nancy Curtin, have argued that, despite the addition of a populist dimension, 'the ideology of the insurrectionary United Irishmen remained very much the same as that of the earlier reformers ${ }^{54}$. Elliott in particular is sceptical of the United Irishmen's potential as social reformers, arguing that despite the 'republicanisation of their political aims there was no corresponding extension of their social programme. By all accounts, therefore, the Irish people might have considered the changes involved in a United Irish republic as little more than a palace revolution ${ }^{55}$. In response, both Jim Smyth and James Quinn have argued that, while the United Irishmen's social beliefs could be characterised as 'unformed and contradictory', their focus on political reform did not preclude serious concern for social amelioration ${ }^{56}$. Indeed, the two were seen as inseparable. Several United Irishmen believed that the economic grievances of the poor were created by the political system and could only be rectified by a reform of that system. Moreover, their political thought (especially in espousing universal manhood suffrage) could lead to innovative thinking on social issues. They looked upon property as a prerequisite for political rights, but they were thus willing to accept a broader definition of property to justify popular political participation, thus the public declaration in 1794 that:

Property is merely the collection of labour [...] and the scattered labour of the lowest ranks is as real and ought to be as really represented as the most fixed and solid property [...]. Giving political power exclusively to property collected, not to the mass of living labour, has been in all ages, and particularly modern times, the true cause of feudality, of vassalage and of aristocratic despotism ${ }^{57}$.

Arguably, it is in these discussions over the role of political equality in producing socioeconomic outcomes, that we can see aspects of the debate between the 'Jacobins' and the 'sans culottes'.

At any rate, some of these ideas allowed for a successful extension of the United Irish system lower down the social scale. By 1795 , certain members of the middle-class Society of United Irishmen were beginning to make overtures to Dublin's artisan clubs. After their suppression in May 1794, the Society began to reconstitute itself as a revolutionary mass movement. This produced an influx of lower class members ${ }^{58}$. This creation of a revolutionary movement was only possible because it was able to build on a fertile culture of lower class political engagement, as expressed through the earlier explosion of working class radical clubs. Kevin Whelan has described how middle-class radicals 'colonised' these smaller societies, and that description certainly seems accurate ${ }^{59}$. By the autumn of 1796, a system of affiliated United Irish societies with a broader social base was being actively organized in Dublin, mainly thanks to the consolidation of various preexisting radical networks. Over the space of the next year and a half, the revolutionary 
underground would not only be consolidated but expanded, a process of mass recruitment which produced a United Irish system of cellular-organized societies in the city $^{60}$.

The prominence of journeymen and apprentices in the revolutionary movement was attested to by the evidence provided by a list of those who availed of a government amnesty and surrendered themselves in Dublin during the summer of 1798, having confessed to 'being engaged in the present rebellion'. The list contains just over a thousand names and presents a picture of Dublin's radical underground, located mainly in city's southwestern manufacturing neighbourhoods and centred on the textile industry - just over $38 \%$ of the names give some form of textile related trade as an occupation. Joining this group are labourers (13\%), the building industry $(7.8 \%)$ and shoemakers (6\% ). While the names included in this amnesty list present a broad sample of Dublin's working classes, it is not a representative one. The amnesty contains an overrepresentation of certain trades such as weaving or shoemaking and an underrepresentation of the construction trades, as well as those involved in services. It is possible that those employed in the construction trades, due to their trade's mobility (i.e. not being based in a workshop but moving from site to site) were not exposed to the same type of 'socialisation' that came through the workplace as in some other trades. A similar observation has been made about the Parisian construction trades during the Revolution, but it is not clear how valid the comparison is ${ }^{61}$. More significant, as Thomas Bartlett has noted, is how few of the people on the Dublin amnesty list appear in directories of the period, indicating a large underclass of disaffected tradesmen and labourers, far below the level of affluence required for inclusion in a directory ${ }^{62}$. Taken cumulatively, this evidence suggests that estimates of 10,000 Dubliners being United Irishmen were not farfetched.

\section{8: The failure of a Dublin Rising}

31 Which raises a very important question: why didn't Dublin successfully rise in revolt? On the surface, the city contained all the ingredients for a popular rising. As discussed, Dublin contained a large and articulate working population, well-versed in the logistics of political mobilization and evidently enrolled into the United Irish movement on a mass scale. Furthermore, leaders within the movement were certainly strategizing how to make use of the city's menu peuple. Lord Edward Fitzgerald, who had witnessed crowd actions in revolutionary Paris, had drawn up plans in which Dubliners would erect barricades of 'hogsheads, carts, cars, counters' to prevent the military from moving through the streets, leaving them vulnerable to attacks from the rooftops and harassment by an irregular force of the city's inhabitants ${ }^{63}$. Given these factors, Dublin's inactivity in 1798 is surprising.

There are, however, several factors that explain this. The sheer numbers of Dublin citizens being enrolled into this secret revolutionary organization had brought problems: lack of discipline, declining quality of recruits, and the penetration of networks by informers. The United Irishmen were particularly vulnerable to police and government spies, especially at the leadership level. In March of 1798, a raid on a meeting of the Leinster Committee (in charge of organizing the surrounding province, but acting effectively as a national body) had resulted in the arrest of the majority of the United Irish executive, removing many able leaders and forcing those remaining to go on the 
run. This was compounded by the arrest of the remaining leaders (the Sheares brothers and Lord Fitzgerald) in the weeks immediately preceding the date set for the rising (23 May). The raid in March had also furnished the government with detailed memoranda concerning United Irish plans for taking Dublin, as well as detailed estimates of their strength within the city, thus alerting authorities to the potential dangers of a rising ${ }^{64}$.

Any potential revolt would also have to contend with a substantial military force garrisoned in the city. In a city of 180,000 people, the local garrison contained upwards of 4000 troops, while the city was home to a similar number of the recently established (and exclusively Protestant) yeomanry force. Unlike the situation in Paris in 1789, the government had little fear concerning the loyalty of the yeomanry, who were dreaded by radicals due to their "possessing a knowledge of the situation of all the streets \&c. and of the inhabitants, and are able to distinguish between the loyal and disloyal ${ }^{65}$. Armed with knowledge of the United Irish network gleaned from government raids, the armed forces enacted a brutal counter-insurgency campaign, mounting regular daily patrols and guards, restricting movement and stopping crowds from gathering. Meanwhile, the local police was similarly tireless in routing out disaffection, aided by being freed from the obligation to obtaining warrants prior to entry and arrest. Moreover, Dublin's geography afforded the authorities certain advantages. The two canals formed a potentially formidable fortification, with the bridges along them spaced so that they could be easily flanked, while within gates and palisades were easily erected on the bridges, controlling movement into the city. The control of potential assembly points, combined with the barricading of the bridges and frequent patrols, ensured that would-be rebels could not easily coordinate with allies either within or without of the city ${ }^{66}$.

To these factors must be added a failure of middle-class leadership, not just at the elite leadership level of the United Irishmen, but lower down the organisation. It was alleged that many more 'middling' members had gotten cold feet concerning the prospects of a Dublin rising, fearing the potential for social unrest. One informer claimed that 'the mercantile and the trading people, even those who have been United men and friends to that system, feel the necessity of repelling an invasion of the city - they feel it from the strongest motives - self-preservation, affection to their relatives and protection of property ${ }^{67}$. The loyalty or neutrality of the 'middling' orders was a key factor in the failure of the rising. Francis Higgins reported that it was the apprentices who were 'most forward and determined for shedding blood in the city, and that it is perfect fear of not being joined by any other than clerks or shopmen which prevents them from rising ${ }^{68}$. After several years of organizing Dublin's workers into a hierarchical revolutionary conspiracy, it may well have been a failure of middle-class leadership, rather than plebeian apathy, that derailed the chances of a city rising. Perhaps this was an indication of possible tensions between the organization's middle-class equivalents of the 'Jacobins' and its respective 'sans-culottes'. Due to the fragmented and suspect nature of much of the documentation (these accounts were often by those seeking amnesty and were rarely disinterested), such an analysis must remain conjectural.

The failure of Dublin to rise had a significant impact on the nature of the rebellion more generally. As the keystone in a plan to set off successive risings throughout the country, its failure largely accounts for the haphazard and chaotic nature of much of subsequent events. As a result, an independent Irish republic was not achieved in 1798. But, if we indulge in counter-factual speculation, might we not ask - if Dublin had risen and revolution enacted, what would a United Irish republic have entailed? Or, more pointedly, 
would a government of United Irishmen have benefited the impoverished tradesmen of Dublin? Perhaps, in this alternate reality of a United Irish republic, men like Arthur o'Connor or the Sheares might have found themselves facing pressure and opposition from the laboring poor that they previously harnessed to their cause. Perhaps Dublin's working-class districts would have become the Irish 'sections révolutionnaires', along the lines of the faubourgs Saint-Antoine or Saint-Michel, exerting pressure on their political leaders to bend towards more socially radical demands. More realistically, a United Irish victory (or a French victory in Ireland) in 1798 would have resulted in Dublin becoming the capital of a puppet state for the Directory, rather than a replication of the situation in Paris during the early years of the revolution. If so, the experience of such 'sister republics' was hardly encouraging. Hugh Gough has argued that such a victory for republican forces in Ireland would only have merely prolonged a violent rebellion before France shrewdly relinquished the country back to Britain as part of a European settlement. Perhaps, in Gough's words, the failure of the 1798 rebellion was 'not a missed opportunity, but a fortunate escape for all three countries' ${ }^{169}$.

\section{Conclusion}

The failure of the planned Dublin rising largely accounts for the subsequent neglect of Ireland's artisan radicals. In subsequent histories, it was the bloodshed in the Irish countryside that understandably captured the most attention, not the tavern clubs of urban workers. Whether it was in heroic biographies of elite figures like Lord Edward Fitzgerald or Theobald Wolfe Tone, or accounts of the Wexford peasantry in 1798, the political activities of Irish artisans receded from view. This was compounded by the fact that the 'Irish Catholic Nation' in the early nineteenth century was ultimately the result not so much of the urban environment, but of the growth of rural sociability, which produced a politicised and disciplined Catholic population, of which Daniel O'Connell was the primary beneficiary. This article has attempted to counter this tendency by demonstrating the presence of a vibrant political underworld in Dublin, consisting of artisans and tradesmen far below the social standing of the standard heroes of Irish nationalist historiography. It does not seek to argue that Dublin's workers were an exact equivalent of the Parisian sans culottes: Dublin was not Paris. However, Dublin's artisans did share many of the same egalitarian aspirations as their Parisian counterparts, as well as imbibing some of the revolutionary ideas that emanated out of Paris (and elsewhere) after 1789. Dublin's artisans, like artisans throughout the Atlantic world, harboured a fierce sense of independence which resonated with the new political ideas of the 'Age of Democratic Revolutions', when terms like 'liberty' and 'independence' acquired new meaning and potency. As David Garrioch has remarked of Parisian journeymen, 'even before the Enlightenment introduced the language of individual liberty and human rights, artisans spoke of their freedoms and rights and condemned "tyranny" "70. In much the same vein, while Ireland's middle classes would develop their own republican and separatist ideology, many of the mental components for this tradition simultaneously existed among Dublin's artisans, if in simpler or embryonic forms. 


\section{NOTES}

1. Mark trugotT, 'Capital Cities and Revolutions', Social Science History, Vol. 19, No.1 Spring, 1995; Lyman JoHnson, The Workshop of Revolution: Plebeian Buenos Aires and the Atlantic World 1776-1810, Durham, Duke University Press, 2011.

2. Thomas BARTLETT, 'Why the History of the 1798 Rebellion Has Yet to Be Written', EighteenthCentury Ireland Vol.15, 1, January 2000, p. 181-190.

3. Saunders' Newsletter (Dublin), 8 June 1798.

4. Letters from a Gentleman in Ireland to his friend at Bath, Cork, 1798, p. 9-10.

5. Richard MUSGRAVE, Memoirs of the Irish Rebellion of 1798, London, 1801, p. 156.

6. A notable exception being Jim SмYTH, The Men of No Property. Irish Radicals and Popular Politics in the Late Eighteenth Century, Basingstoke, Macmillan, 1992.

7. Gwynn williams, Artisans and Sans-Culottes: Popular Movements in France and Britain during the French Revolution, London, Edward Arnold Publishers, 1968; Gary NASH, The Urban Crucible: The Northern Seaports and the Origins of the American Revolution, Cambridge Mass., Harvard University Press, 1979.

8. Richard ANDREWS, 'Social Structures, Political Elites and Ideology in Revolutionary Paris 1792-1794: A Critical Evaluation of Albert Soboul's ‘Les Sans-Culottes Parisiens en L'An II” Journal of Social History (1985), p. 71-112; Michael SONENSCHER, Sans-Culottes: An Eighteenth-Century Emblem in the French Revolution, Princeton, 2008.

9. Niall GILLESPIE, Irish Political Literature c 1778-1832: The Imaginative Prose, Poetry and Drama of the Irish Volunteers, the United Irish Society and the Anti-Jacobins, PhD dissertation, Trinity College Dublin, 2013.

10. Daniel Roche, Le Peuple de Paris: essai sur la culture populaire au XVIII ${ }^{e}$ siècle. Paris, Aubier Montaigne, 1981; David GARRIOCH, The Making of Revolutionary Paris, Oakland, University of California Press, 2002.

11. David DICKSON, 'The Place of Dublin in the Eighteenth-Century Irish Economy' in T. M. DEVINE and David DICKSON (eds), Ireland and Scotland 1600-1850: Parallels and Contrast in Economic and Social Development, Edinburgh, Donaldson Press, 1983.

12. Colm LenNon, 'The Print Trade, 1700-1800' in R. GILLEPSIE and A. HADFIELD (eds), The Oxford History of the Irish Book in English Vol. III 1550-1800, Oxford, Oxford University Press, 2005.

13. Jan DE VRIES, European Urbanization, 1500-1800, Cambridge, Mass., Harvard University Press, 1984.

14. John WARbUrton, James Whitelaw, and Robert WALSh, History of the City of Dublin, 2 Volumes, London, 1818, Vol. II, p. 983-985.

15. Patrick FAGAN, 'The Population of Dublin in the Eighteenth Century with Particular Reference to the Proportions of Protestants and Catholics', Eighteenth Century Ireland, Vol. 6, 1991, p. 146-148.

16. British Parliamentary Papers, House of Commons, 'Evidence taken before the Committee in the Irish House of Commons on the subject of the Legislative Union c.1800', H. C. XXXV.54, 1833 [517], p. 10-11.

17. David GARRIOCH and Michael SONENSCHER, 'Compagnonages, Confraternities and Associations of Journeymen in Eighteenth-century Paris’ European History Quarterly, 1986.

18. Morning Post (Dublin), 9 June 1792; Freeman's Journal (Dublin), 4 October 1792.

19. Hibernian Journal (Dublin), 21 March 1792 
20. Luke O'Brien to Dublin Castle, 1803, quoted in Fergus D'ARCY (ed.), Workers in Revolution, Dublin, National Archives of Ireland, 1989, p. 33.

21. Sean J. ConNolly, Religion, Law and Power, Oxford, Oxford University Press, 1992, p. 101.

22. Sean MURPHY, 'Charles Lucas and the Dublin Election of 1748-1749' Parliamentary History, Vol. $2,1983$.

23. Charles LUCAS, Address no.2, Dublin, 1749; The Censor no.12, Dublin, 1749.

24. Jim SмYтH, 'Republicanism before the United Irishmen: The Case of Dr Charles Lucas' in D. George boyce, Robert eccleshall and Vincent Geoghegan (eds), Political Discourse in Seventeenthand Eighteenth-Century Ireland, Basingstoke, Palgrave, 2001, p. 248-249.

25. Jacqueline HILL, 'Allegories, Fictions and Feigned Representations: Decoding the Money Bill Dispute 1752-6', Eighteenth Century Ireland, 2006, p. 84.

26. Robert E. BURNS, Irish Parliamentary Politics in the Eighteenth Century, Vol. II: 1730-60, Washington D.C., Catholic University of America Press, 1991, p. 171.

27. Padhraig HIGGINS, A Nation of Politicians. Gender, Patriotism and Political Culture in Late EighteenthCentury Ireland, Madison Wisconsin, University of Wisconsin Press, 2010, p. 223-231.

28. Alexander мURDOCH, 'The Importance of Being Edinburgh: Management and Opposition in Edinburgh Politics, 1746-1784', The Scottish Historical Review, Vol. 62, No. 173, April, 1983; Bob HARRIS, The Scottish People and the French Revolution, London, Pickering \& Chatto, 2008, p. 20-22.

29. Niall ó CIOSÁIN, Print and Popular Culture in Ireland, Basingstoke, Palgrave, 1997, p. 38.

30. Mary POLLARD, Dublin's Trade in Books 1550-1800, Oxford, Oxford University Press, 1989, p. 210.

31. ANONYMOUS, The Clothiers Letter to the inhabitants of the Liberties, Dublin, 1759.

32. Kevin Whelan, The Tree of Liberty. Radicalism, Catholicism and the Construction of Irish Identity, 1760-1830, Cork, Cork University Press, 1996, p. 77.

33. Freeman's Journal (Dublin), 25 September 1794.

34. Freeman's Journal (Dublin), 11 December 1794.

35. Freeman's Journal (Dublin), 18 August 1795.

36. Freemans Journal (Dublin), 2 July 1795.

37. Michael SCRIVENER, Seditious Allegories: John Thelwall and Jacobin Writing, Pennsylvania, 2001, p. 21-41.

38. Robert DARNTON, The Great Cat Massacre and Other Episodes in French Cultural History, New York, Allen Lane, 1984.

39. DAVID DICKSON 'Paine and Ireland' in DICKSON, KEOGH and WHELAN (eds.) The United Irishmen: Republicanism, Radicalism and Rebellion, Dublin, Lilliput Press, 1993 p. 135-150; NANCY CURTIN, The United Irishmen: Popular Politics in Ulster and Dublin 1791-1798, Oxford, Oxford University Press, 1994, p. 178-181.

40. Anonymous, Some Observations on a late address titled Thoughts on the Present Crisis, Dublin, 1797.

41. Eric FONER, Tom Paine and Revolutionary America, Oxford, Oxford University Press, 1976, p. 156.

42. Gregory ClaEYS, Thomas Paine: Social and Political Thought, Cambridge, Cambridge University Press, 1989, p. 64, 99-101.

43. W. H. REID, The Rise and Dissolution of the Infidel Societies in the Metropolis, London, 1800; Gwynne WILliAms, ‘Morgan John Rhys and Volney's Ruins' Bulletin of Celtic Studies, n²0, 1962.

44. Robert R. PALMER, The Age of Democratic Revolutions, 2 Volumes Princeton N.J., Princeton University Press, 1964, vol. II, p. 512; Peter LINEBAUGH and Marcus REDIKER, The Many Headed Hydra, London, Verso Press, 2000, p. 341-344.

45. Kevin WHELAN, The Tree of Liberty, op. cit., p. 63.

46. Richard MUSGRAVE, Memoirs of the Irish Rebellion of 1798, op. cit., p. 486.

47. National Archives of Ireland (NAI), Rebellion Papers (RP) 620/18/3/38 and 620/18/14/138.

48. An intriguing, although now somewhat dated, discussion can be found in Ferenc FEHER, The Frozen Revolution: An Essay on Jacobinism, Cambridge, Cambridge University Press, 1987. 
49. Robert B. MCDOWELL, 'The Personnel of the Dublin Society of United Irishmen, 1791-4' Irish Historical Studies, Vol. 2, No. 5, Mar. 1940, p. 5-17. For a discussion of the internal factions of the first Dublin Society in terms of class, see Michael DUREY, 'The Dublin Society of United Irishmen and the Politics of the Carey-Drennan Dispute 1792-1794' The Historical Journal, vol. 37, No. 1, March 1994, p. 89-111.

50. James S. Donnelly, 'Propagating the Cause of the United Irishmen', Studies: An Irish Quarterly Review,1980; Maru THUENTE, The Harp Restrung: The United Irishmen and the Rise of Literary Nationalism, Syracuse, NY, Syracuse University Press, 1994.

51. David DICKSON, 'Taxation and Disaffection in Late Eighteenth-Century Ireland' in Samuel CLARKE and James S. DONNELLY (eds), Irish Peasants violence and political unrest 1780-1914, Manchester, Manchester University Press, 1983, p. 37-63.

52. Frank GEARY and Tom STARK, 'Trends in Real Wages during the Industrial Revolution: a view from across the Irish sea', The Economic History Review, Vol. LVII, No. 2, 2004, p. 383.

53. Kevin WHELAN, 'Introduction to 'The Poor Man's Catechism' Labour History, No. 75, 1998.

54. Nancy CURTIN, The United Irishmen: Popular Politics in Ulster and Dublin, 1791-1798, Oxford, Oxford University Press, 1994, p. 29.

55. Marianne Elliott, Partners in Revolution. The United Irishmen and France, New Haven, Yale University Press, 1982, p. 228.

56. Jim SMYTh, The Men of No Property, op. cit., p. 165.

57. James QUINN, 'The United Irishmen and Social Reform', Irish Historical Studies, 1998, p. 190-191.

58. Robert B. MCDOWELL, 'The Personnel of the Dublin Society of United Irishmen, 1791-4', art. cit.; Nancy Curtin, The United Irishmen, op. cit., p. 135-139.

59. Kevin WHELAN, The Tree of Liberty, op. cit., p. 79.

60. Thomas GRAHAM, 'The Transformation of the Dublin Society of United Irishmen into a MassBased Revolutionary Organisation, 1791-6' in Thomas BARTLETT et al. (eds), 1798: A Bicentenary Perspective, Dublin, Four Courts, 2003, p. 136-146.

61. David GARRIOCH, Neighbourhood and Community in Paris 1740-1790, Cambridge, 1986, p. 107-110.

62. Thomas BARTLETT (ed.), Revolutionary Dublin, 1795-1801: The Letters of Francis Higgins to Dublin Castle, Dublin, Four Courts Press, 2004, p. 371-373.

63. Copy of a paper found in a writing box belonging to Lord Edward on $12^{\text {th }}$ March' reproduced in Richard MUSGRAVE, Memoirs of the Irish Rebellion of 1798, op. cit., Appendix No. XXI.

64. Thomas GRAHAM, “'A Union of power”? The United Irish Organisation, 1795-1798' in David DICKSON et al. (eds), The United Irishmen: Republicanism, Radicalism and Rebellion, Dublin, Lilliput Press, 1993, p. 244-255.

65. Thomas Boyle to Edward Cooke, 29 May 1798, NAI, RP 620/18/3/145.

66. Allan BLACKSTOCK, An Ascendancy Army: The Irish Yeomanry 1796-1834, Dublin, Four Courts, 1998, p. $118,148-149$.

67. 'J.W.' [Leonard McNally] to Cooke, [late May/Early June] 1798, NAI, RP 620/10/121/155.

68. Francis Higgins to Edward Cooke, June 2 1798, in Thomas Bartlett (ed.), Revolutionary Dublin, op. cit., p. 246-247.

69. Hugh GOUGH, 'France and the 1798 Rebellion' in Cathal POIRTEIR (ed.), The Great Irish Rebellion of 1798: The Thomas Davis Lectures, Dublin, Mercier Press, 1998, p. 47-48.

70. David GARRIOCH, The Making of Revolutionary Paris, op. cit., p. 79. 


\section{ABSTRACTS}

In Ireland during the 1790s, middle-class radicals and republicans were denigrated by conservatives as Irish 'Jacobins'. Simultaneously, Irish urban workers (tradesmen, journeymen and apprentices) came to be seen as a potentially dangerous force which resembled - not the bourgeois Jacobins - but the Parisian Sans-culottes. Despite very significant differences between Dublin and Paris, the workers in each city shared certain features, such as a strong egalitarian ethos and a highly literate culture of remonstrance and protest. While Dublin, unlike Paris, was not the site of a successful revolution, it too contained a vibrant radical underworld in which urban workers voiced their political aspirations. This article examines some of the factors that contributed to Dublin's network of artisan clubs, such as municipal politics, a lively print trade, the ethos of the city guilds, and the interactions between Irish Parliamentarians and the urban 'mob'. It then examines how Dublin's artisan radical clubs interacted with, and were eventually incorporated into, the middle-class United Irish Societies. It finally suggests that Dublin's artisans represent an intriguing case of how revolutionary doctrines were received in Ireland at the popular level.

En Irlande, au cours des années 1790 , les radicaux et républicains issus des classes moyennes furent dénoncés par les conservateurs comme étant des « jacobins » irlandais. Parallèlement, les ouvriers du milieu urbain (artisans, compagnons et apprentis) en vinrent à être perçus comme une force potentiellement dangereuse qui ressemblait non pas aux jacobins «bourgeois » mais aux sans-culottes parisiens. Malgré des différences de taille entre Dublin et Paris, les ouvriers de chacune des deux villes partageaient certaines caractéristiques, telles une forte aspiration égalitaire et une culture, synonyme de forte alphabétisation, de remontrances et de protestations. Tandis que Dublin, contrairement à Paris, n'a pas été le théâtre d'une révolution, elle a aussi été le foyer d'un monde souterrain radical et animé dans lequel les ouvriers donnèrent voix à leurs aspirations politiques. Cet article interroge certains des facteurs qui ont contribué à la formation d'un réseau dublinois de clubs d'artisans, parmi lesquels la vie politique municipale, le dynamisme de l'imprimerie, les valeurs des guildes, et les interactions entre le Parlement et la «foule» urbaine. Il analyse ensuite comment les clubs radicaux des artisans dublinois interagissaient avec, et furent finalement absorbés par les sociétés des Irlandais Unis issues de la classe moyenne. Il suggère, enfin, que les artisans et ouvriers de Dublin constituent un cas révélateur de la manière dont les doctrines révolutionnaires furent reçues en Irlande par les couches populaires.

\section{INDEX}

Keywords: Dublin, Artisan, Radicalism, Labour, Popular Politics, Irish Republicanism

Mots-clés: Dublin, artisans, radicalisme, ouvriers, politisation, républicanisme irlandais 


\section{AUTHOR}

\section{TIMOTHY MURTAGH}

Trinity College Dublin,

Chercheur pour le Dublin City Council 